\title{
Climate Variability Adaptation Strategies: Challenges to Livestock Mobility in South-Eastern Burkina Faso
}

\author{
Charles L. Sanou ${ }^{1,2^{*}}$, Daniel N. Tsado', André Kiema ${ }^{3}$, Julia O. Eichie ${ }^{1,2}$, \\ Appollonia A. Okhimamhe ${ }^{1,2}$ \\ ${ }^{1}$ Federal University of Technology, Minna, Nigeria \\ ${ }^{2}$ West African Science Service Centre on Climate Change and Adapted Land Use, Ouagadougou, Burkina Faso \\ ${ }^{3}$ Institut de l'Environnement et de Recherches Agricoles, Région du Centre, Ouagadougou, Burkina Faso \\ Email: *sclamoussa@gmail.com, *sanou.c@edu.wascal.org
}

How to cite this paper: Sanou, C.L., Tsado, D.N., Kiema, A., Eichie, J.O. and Okhimamhe, A.A. (2018) Climate Variability Adaptation Strategies: Challenges to Livestock Mobility in South-Eastern Burkina Faso. Open Access Library Journal, 5: e4372. https://doi.org/10.4236/oalib.1104372

Received: January 24, 2018

Accepted: February 25, 2018

Published: February 28, 2018

Copyright $\odot 2018$ by authors and Open Access Library Inc.

This work is licensed under the Creative Commons Attribution International License (CC BY 4.0).

http://creativecommons.org/licenses/by/4.0/

\begin{abstract}
This research work aims to study the perceptions of pastoralists and agropastoralists on climate change impacts on mobile herding and the effectiveness of herders' adaptive strategies within Kompienga Province, south-eastern region of Burkina Faso. In order to achieve this aim, survey data were retrieved from 271 respondents and analysed. From respondents' perceptions, climate change is real and is negatively affecting forage availability (in quality and quantity); livestock production and reproduction performances; herders' practices, their livelihoods and the cohabitation of herding and crop farming. To overcome the increasing constraints the pastoral herding is facing, sound and urgent actions need to be undertaken by Burkina Faso government. These actions include: 1) providing the grazing reserves with necessary facilities such as perennial reservoirs; 2) conducting research to improve breeds that would adapt to current climatic conditions; 3 ) encouraging and supporting gradual shift of herders from mobile herding to the sedentary breeding; 4) supporting and organizing forage production by farmers. At short term an effective cross-border framework could be created to seek for sound solutions to secure the mobility of herds within ECOWAS territory.
\end{abstract}

\section{Subject Areas}

Agricultural Engineering, Agricultural Science, Animal Behavior,

Atmospheric Sciences, Environmental Sciences, Environmental Sciences

\section{Keywords}

Adaptation, Climate Variability, Pastoralism, Perception 


\section{Introduction}

Climate change constitutes one of the biggest challenges of the development process over the last century. This phenomenon is increasingly threatening communities' livelihoods in West Africa and particularly in Burkina Faso. Indeed, recent climate deterioration makes its economy gradually vulnerable mainly through the decline in rainfall that negatively affects pasture biomass and crop yield. The future climate of Burkina Faso will experience a decrease in rainfall $(-3.4 \%$ by 2025 and $-7.3 \%$ by 2050$)$ coupled with a very strong seasonal and inter-annual variability of climatic factors [1]. This situation is likely to further affect rangelands productivity [2] [3] and jeopardize the development of livestock production in Burkina Faso. Yet livestock occupies a prominent place within national economy of Burkina Faso after gold and cotton. The livestock sector contributes about $18 \%$ to Gross National Product (GNP) and accounts for $26 \%$ of exports and constitutes a source of incomes for nearly $80 \%$ of the population [4]. Livestock farming relies largely on pastoral herding in the country. It is an extensive animal rearing characterized by herds mobilities and the exploitation of natural forage whose productivity is underpinned by climatic conditions and soil quality. Mobility consists in a flexible solution enabling a sound exploitation of variable resources [5] by mobile herds. Accordingly, over the past 10 years, this mobility has been perceived as increasing the resilience of rural households in semi-arid Africa to climate change and variability [6]. Similarly, many authors argued that mobile herding, a long-term adaptation way to climate variability, should continually play a paramount role among livelihood strategies in rural area [7] [8] [9] [10] [11]. However, how long will this mobility contribute to reinforce the resilience of pastoralists in South-Eastern Burkina Faso? This interrogation is raised because of the increased challenges to which mobile herding is gradually confronted in West Africa. Among challenges there are the reduction of grazing land size [12]-[20], the obstruction of livestock routes [21], the reduction of watering points, the qualitative and quantitative decline in forage biomass [21] [22] [23] [24] and the recrudescence of conflicts between land users. These challenges affect livestock production and reproduction performance and finally the livelihoods of pastoral communities. Given these challenges one might wonder about the relevance of the adaptation strategies against climate variability and related hazards. A focus will be done on livestock mobility strategy (internal mobility and cross border transhumance). Understanding geographical patterns of this mobility as well as its opportunities and constraints, is critical in the definition of support actions to pastoralists adaptation to increasing climatic variability [6]. The current study highlights recent changes in livestock mobility due to climate change and variability. The results will provide information on emergent constraints and give room for good management policies. The research hypothesis is that: "recent changes in climate conditions is gradually compromising the effectiveness of livestock mobility as adaptation strategy to climate change and variability". 


\section{Materials and Methods}

\subsection{Study Area}

Kompienga province located in south-eastern region of Burkina Faso at the border with Togo and Benin Republic, constitutes the study area of the current research (Figure 1). It lies between longitude $0^{\circ} 30^{\prime} 4.96 " \mathrm{E}$ and $1^{\circ} 22^{\prime} 22.25^{\prime \prime} \mathrm{E}$ and $10^{\circ} 56^{\prime} 16.85^{\prime \prime} \mathrm{N}$ and $11^{\circ} 27^{\prime} 21.09^{\prime \prime N}$. About $2 / 3$ of the total land area of the province $\left(6998 \mathrm{~km}^{2}\right)$ is occupied by forest and wildlife reserves [25]. The climate of Kompienga is Sudanian, characterized by a longer dry season (October to April). The annual rainfall fluctuates between 700 and $1000 \mathrm{~mm}$ on average [26] while the mean temperature over the province is $26^{\circ} \mathrm{C}$ [27]. The whole of the eastern region, is characterized by a peneplain with some hills around Pama [26]. The leached tropical ferruginous soils predominate, sometimes with hydromorphic soils found along rivers [28]. The flora is dominated by shrub and woody savannahs. These savannahs are dotted with islands of clear forest formations and furrowed by woody savannahs, clear forests and gallery forests, especially in the vicinity of rivers [29] [30] [28]. The population dynamic in the study area is important and the population tripled in two decades after the construction of the Kompienga damrepresenting annual growth rates of $5.7 \%$ between 1985 and 2006. The projected population based on estimated growth rate of $4.41 \%$ was

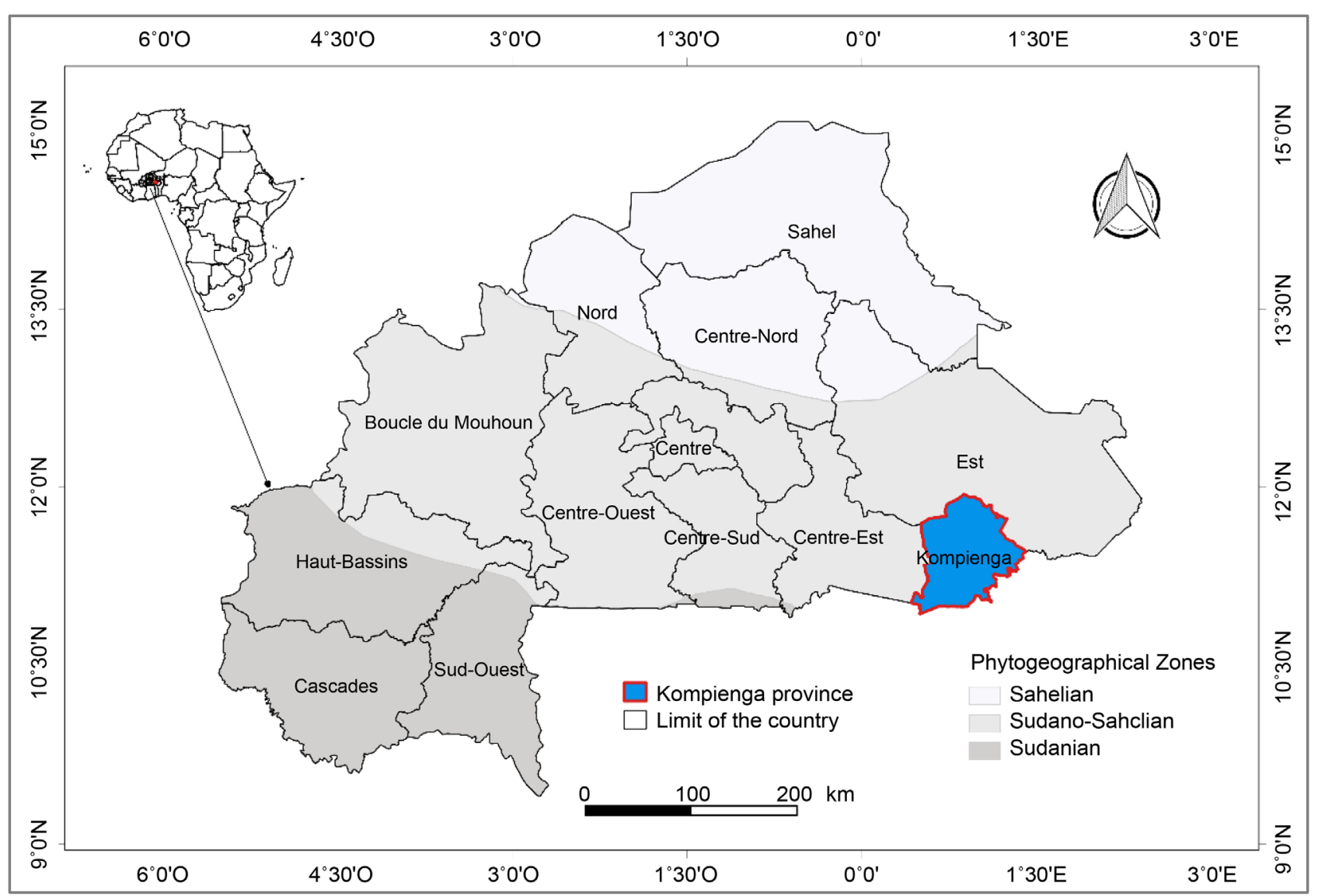

Figure 1. Burkina Faso showing Kompienga province (source: Institut Geographique du Burkina Faso). 
102,645 peoples in 2013 which was four times more than 1985 figure $(23,818)$ [31] [32].

\subsection{Data Collection}

The research used household survey data collected in twelve out of thirty-eight (38) villages in Kompienga province. The selection of these villages was based on anyone of the following criteria: 1) recurrence of conflicts among land users; 2) constraints in range lands and other pastoral resources conditions. The targeted respondents of the study were pastoralists and agro-pastoralists household heads and respectively classified as owner of 10 - 25 cattle and more than 25 cattle. A total of 271 respondents (Table 1 ) were involved in the study representing, according to $\mathrm{RGPH}^{1}$ of 2006 [31], 5.3\% of the total household number (5103 households) of the villages in the study area. Data collection was conducted through individual survey following these steps:

1) a questionnaire was first designed on farmers' perception on climate change and the impacts of this latter phenomenon on mobile herding. This questionnaire first written in English was then translated into French to ensure a better translation of the questions in local languages by the translator; 2) the survey was carried out through an individual interview of household' heads in each village.

Table 1. Respondents involved in the study.

\begin{tabular}{cccc}
\hline \multirow{2}{*}{ Villages } & \multicolumn{3}{c}{ Main activities } \\
\cline { 2 - 4 } & Pastoralism $^{*}$ & Agro-pastoralism ${ }^{* *}$ & Total \\
\hline Nadiagou & 16 & 11 & 27 \\
Oumpougoudeni & 7 & 20 & 27 \\
Mamanga & 13 & 4 & 17 \\
Kaboanga & 11 & 17 & 28 \\
Kalmama & 6 & 12 & 18 \\
Bombantangou & 2 & 7 & 9 \\
Folpodi & 14 & 7 & 21 \\
Madjoari & 3 & 2 & 5 \\
Bounou & 14 & 4 & 18 \\
Diabiga & 3 & 17 & 20 \\
Kpankpaga & 41 & 19 & 60 \\
Kompienga & 18 & 3 & 21 \\
Total & 148 & 123 & 271 \\
\hline
\end{tabular}

In this study, ${ }^{2}$ pastoralism ${ }^{\star}$ is referred as a socio-economic system and way of life based on a mobile or extensive livestock herding. On the other hand, ${ }^{3}$ agro-pastoralism ${ }^{* *}$ is a form of farming that combines cropping and mobile livestock farming.

${ }^{1}$ Recensement Général de la Population et de l'Habitation.

${ }^{2}$ Pastoralism definition from https://en.wiktionary.org/wiki/pastoralism.

${ }^{3}$ Agro-pastoralism definition from https://en.wiktionary.org/wiki/agropastoralism. 


\subsection{Data Analysis}

Statistical analysis was carried out on data collected from respondents. The Statistical Package for Social Science (SPSS version 23) software was used to code and analyse these data exported from Sphinx 4.5. Results obtained were presented as charts and tables. Frequency analyses and Pearson's chi-square $\left(\chi^{2}\right)$ test were used to analyse respondents' statements related to climate change impacts on pastoral herding. Statistical test significance was set at $5 \%(\mathrm{p}<0.05)$. The computational formula of thechi-square $\left(\chi^{2}\right)$ is:

$$
\chi^{2}=\sum \frac{\left(f_{o}-f_{e}\right)^{2}}{f_{e}}
$$

where $\chi^{2}$ is the Chi-square; $f_{o}$ denotes the frequency of the observed data and $f_{e}$ is the frequency of the expected values.

\section{Results and Discussion}

\subsection{Pastoralists and Agro-Pastoralists' Perceptions on Climate Change or Variability}

From respondents' perspective climate is undoubtedly changing for worse in Kompienga province over the last decades (Figure 2). While $93.4 \%$ of respondents asserted that temperature is increasing, the rainfall amount, intensity and the length of rainy season were said to be decreasing by respectively $97.8 \%$, $97.4 \%$ and $94.5 \%$ of respondents. $90 \%, 58.3 \%$ and $92.6 \%$ of respondents reported an increase in the occurrence of strong winds, floods and animals' diseases;

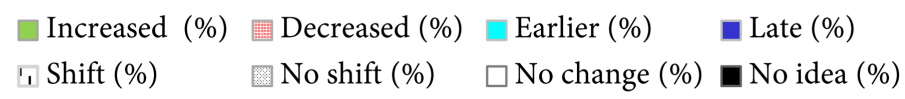

Occurrence of animal famine

Occurrence of animal deseases

Wettest month of the rainy season

End of the rainy season
Onset of the rainy season

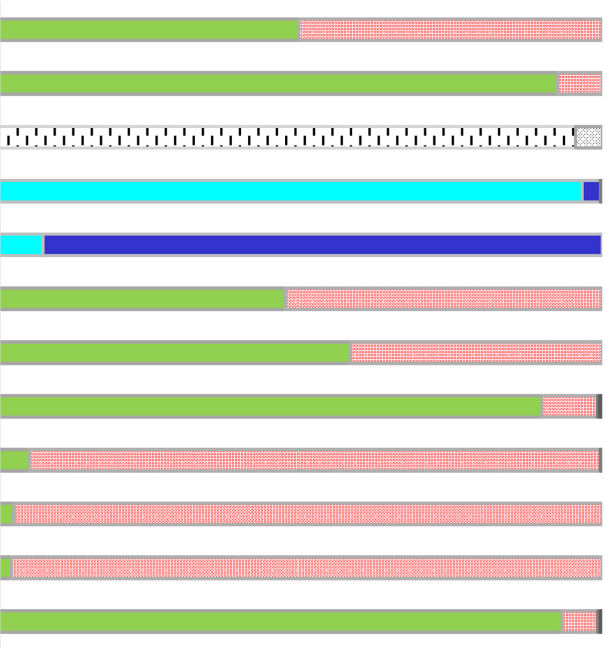

$\begin{array}{llllll}0 & 20 & 40 & 60 & 80 & 100\end{array}$

Frequency (\%)

Figure 2. Perception of pastoralists and agro-pastoralists $(n=271)$ on climate change and climatic hazards in Kompienga province. 
92.6\% stipulated a late onset of the rainy season, while its cessation is early (96.7\% of respondents). Similar results were obtained in the eastern regions of Burkina Faso [24] [33], where the authors found out from respondents' perceptions a decrease in rainfall, an increase in temperature associated with strong winds, a shift in rainfall onset and cessation. Similarly, [34] found from $98 \%$ of respondents, change in the overall climate pattern within Sub-Saharan West-Africa. Furthermore, [35] indicated from respondents' perceptions a pejoration in rainfall conditions. However, changes perceived by respondents were not always in agreement with the observed climate data as indicated by [35] [36] and [20]. The pejoration of climate conditions is not without consequences in South-eastern Burkina Faso where the economy is underpinned by rain related activities.

\subsection{Respondents Perceptions on the Impacts of Climate Change and Variabilities on Livestock and Herders' Livelihoods}

Although, there are many climate change impacts on livestock [20] [24] [33], the respondents mentioned the following as the most important (Table 2). These are affecting mobile herding during the last decades within Kompienga province. The impacts are visible on livestock (Table 2), herders (Table 3 ) and their practices (Figure 3). Indeed, 98.9\%, 99.6\% and 49.4\% of respondents respectively reported a drop-in milk production, an excessive loss of body weight by livestock and a decline in yearly parturition of calves per cow. On the other hand, $98.2 \%$ reported an increase of infectious and parasitic diseases and emergence of new animal diseases. These results corroborate the findings of [20] [22] [37] [38]. These authors asserted that climate changes affect livestock production performance (offspring numbers, milk and meat yields) and also causes the emergence of new Livestock diseases associated with high mortality. In addition, the combined effects of high temperatures, low rainfall, high evapotranspiration and

Table 2. Respondent's perceptions on climate change impacts on mobile herds over last 10 years $(n=271)$.

\begin{tabular}{|c|c|c|c|c|c|}
\hline \multirow{2}{*}{ Climate change impacts } & \multicolumn{5}{|c|}{ Agree (\%) } \\
\hline & Total & Pastoralist & Agro-pastoralists & $\chi^{2}\left(\mathrm{df}^{*}\right)$ & p-value \\
\hline $\begin{array}{l}\text { Animals travel longer } \\
\text { distances to feed and drink }\end{array}$ & 97.8 & 53.9 & 43.9 & $1.66(2)$ & 0.44 \\
\hline $\begin{array}{l}\text { Decrease in the number } \\
\text { of births per year }\end{array}$ & 49.4 & 26.9 & 22.5 & $0.002(1)$ & 0.97 \\
\hline Drop in Milk production & 98.9 & 54.6 & 44.3 & $3.65(1)$ & 0.06 \\
\hline Excessive loss of weight & 99.6 & 54.6 & 45.0 & $1.21(1)$ & 0.27 \\
\hline $\begin{array}{l}\text { Increase of infectious and } \\
\text { parasitic diseases }\end{array}$ & 98.2 & 54.6 & 43.5 & $6.13(1)$ & $0.01^{*}$ \\
\hline $\begin{array}{c}\text { Appearance of new animals' } \\
\text { diseases }\end{array}$ & 98.2 & 53.5 & 44.6 & $0.06(1)$ & 0.80 \\
\hline
\end{tabular}

*df: degrees of freedom. 
Table 3. Respondent's perceptions on climate change impacts on pastoral herder's livelihoods over last 10 years $(n=271)$.

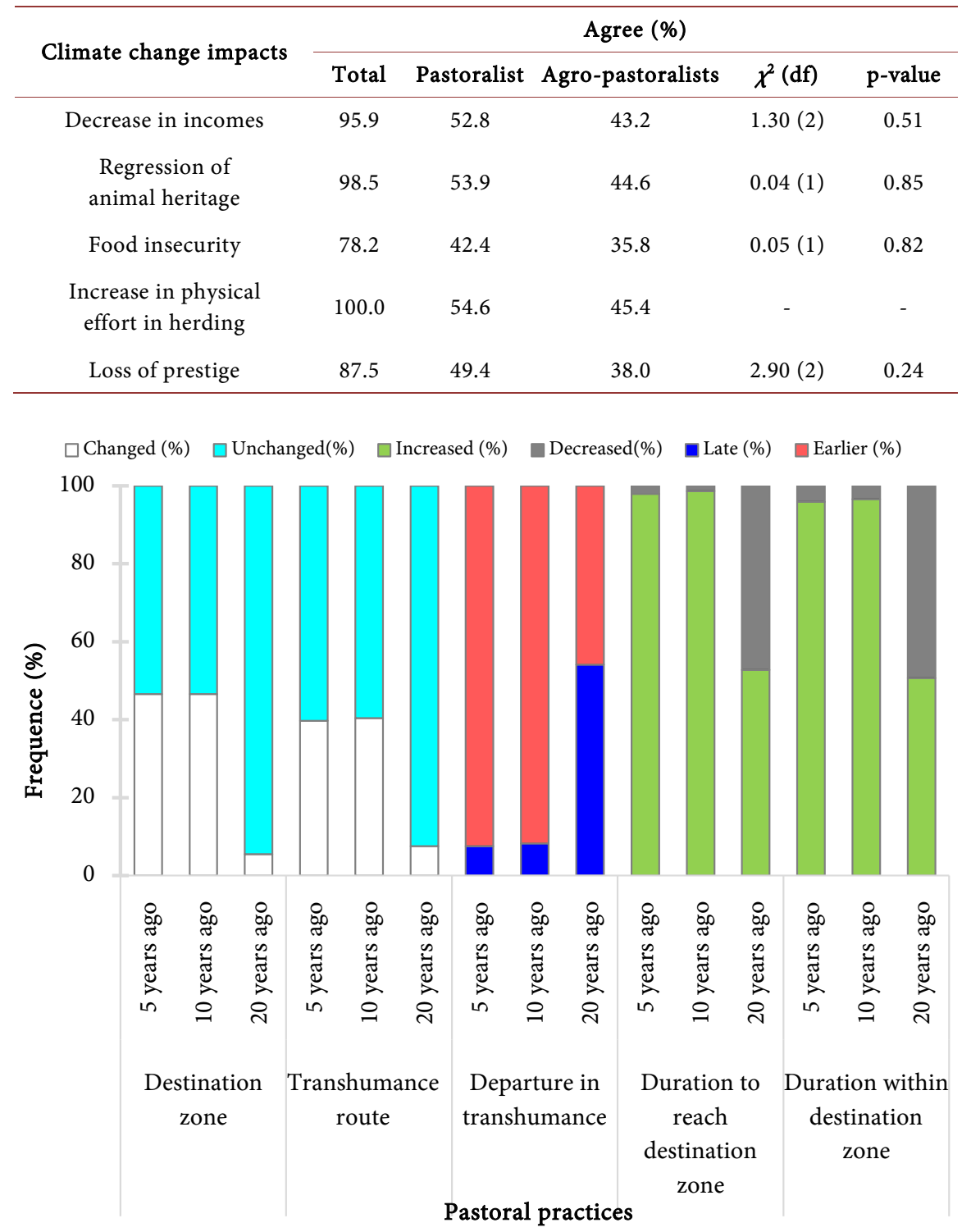

Figure 3. Perception of pastoralists and agro-pastoralists $(n=271)$ on climate change impacts on pastoral practices.

high incidence of drought will have a negative impact on livestock production performances [39]. Apart from the occurrence of infectious and parasitic diseases, no significant $(\mathrm{p}<0.05)$ differences were noticed between pastoralists and agro-pastoralists' perceptions on the impacts of climate change and variabilities (CCV) on mobile herds.

Moreover, from respondents' perspective, climate change is negatively affecting herders' livelihoods (Table 3). A decrease in incomes, a regression of animal heritage, food insecurity, increase in physical effort in herding and loss of prestige were noticed respectively by $95.9 \%, 98.5 \%, 78.2 \%, 100 \%$ and $87.5 \%$ of respondents. This is consistent with the results of [40]. Indeed, [40] attest that cli- 
mate change impacts could affect severely pastoralists' livelihoods. Dependent on rangelands conditions, this could happen through the numbers of animals that they can keep, livestock productivity, potential loss of animals during the dry season, and higher amplitudes of cross-border transhumance in search of pasture and water. No significant difference $(\mathrm{p}<0.05)$, was found between the perceptions of pastoralists and agro-pastoralists on the impacts of CCV on herders' livelihoods.

Furthermore, climate deterioration is negatively affecting herds' transhumance over the last decades (Figure 3). About $46.6 \%$ of respondents reported changes in destination zone respectively over last 5 and 10 years while $39.7 \%$ and $40.4 \%$ reported changes in paths followed by transhumant herds respectively over 5 years and 10 years ago. For the departure period in transhumance, respondents reported that it has been earlier over the last decades. Indeed, almost $92.5 \%$ and $91.8 \%$ of the respondents indicated earlier departure respectively over the last 5 to 10 years. However, at least half of the respondents reported an increased duration within and to reach destination zones. Thus, 5, 10 and 20 years ago durations to reach receptions zones have increased respectively for $97.9 \%$, $98.6 \%$ and $52.7 \%$ of respondents while $95.9 \%, 95.6 \%$ and $50.7 \%$ reported an increased duration within these zones. In such conditions the effectiveness of livestock mobility (which have been for long time an adaptation strategy to climate variability) and the related practices appears to be gradually challenged in Burkina Faso. The reference [41] similarly found changes in mobility patterns in Mongolia, but contrary to the current study it was noticed a reduction in the distance travelled by herds during the seasonal movements. Early departure in transhumance and the increased duration of livestock within destination zonescould have reinforced transhumant resilience as new alternatives to adapt to climate change. Unfortunately, these alternatives are gradually compromised. Indeed, recently, the main host countries (Benin Republic and Togo) have established official dates of entry and release of transhumant herds from their countries. In respondents' perspectives, the authorized periods set (3 to 4 months) [42] [43] are far shorter than the current necessary duration(about 6 months). This situation will negatively affect pastoral herding in Burkina Faso if sound and comprehensive solutions are not found by countries leaders involved in regional mobility of livestock.

\subsection{Challenges of Pastoral Herders' Adaptations Strategies and Their Effectiveness}

Respondents adopt some practices to cope with the negative effects induced by climate hazards and their impacts (Table 4). The most important strategies to adapt to drought are: Feed supplement (99.3\%), which is the utilisation of feed concentrates of high nutritional value (cottonseed cake, cereals) and multi-nutritional blocks in support of forages. The second most important adaptation strategy to drought identified by the respondents was transhumance (96.3\%). This consists sound and sustainable exploitation of sparse resources 
Table 4. Respondents' adaptations measures to main climate hazard and their impacts on mobile herding activities $(\mathrm{n}=271)$.

\begin{tabular}{ccccc}
\hline Adaptation measures & Drought & $\begin{array}{c}\text { Inadequate } \\
\text { grazing land }\end{array}$ & $\begin{array}{c}\text { Inadequate } \\
\text { water }\end{array}$ & $\begin{array}{c}\text { Livestock } \\
\text { diseases }\end{array}$ \\
\hline Use of crop residues & 93.7 & 93.4 & 0.0 & 1.8 \\
Use of fodder trees & 76.8 & 77.1 & 0.0 & 1.5 \\
Rainwater harvesting & 1.8 & 0.0 & 17.3 & 0.0 \\
Use of ground water & 65.3 & 3.0 & 65.3 & 0.0 \\
Forage cropping & 4.4 & 19.6 & 0.0 & 0.0 \\
Fattening/Destocking & 88.2 & 87.1 & 46.9 & 3.3 \\
Transhumance & 96.3 & 97.0 & 90.8 & 37.3 \\
Abandonment of pastoral & 3.7 & 12.5 & 8.9 & 6.3 \\
herding & 94.5 & 32.8 & 92.3 & 39.5 \\
Prayers and other rites & 99.3 & 98.2 & 2.6 & 32.8 \\
Food supplement & & & & \\
\hline
\end{tabular}

between a zone of deficit and destination zone of suitable environment (rich pasture, abundance of water, free from animals' diseases). Abandonment of pastoral herding (3.7\%) and Prayers or other rites (94.5\%), are practices of last resort where herders are desperate seeing their livestock die as a result of lack of resources (feed, water). Prayers and performance of other rites may not be seen as an effective form of adaptation to drought, however, for the respondents it is a major practice. Crop residue utilisation that involves feeding of livestock on stems of crops (corn, millet or other crops) after harvest is another form of adaptation strategy widely practiced by the respondents (93.7\%). The use of fodder trees consists of grazing livestock on leaves, fruits or flowers of some trees qualified as fodder trees. About $76.8 \%$ of the respondents adopted this strategy to cope with drought. Access to water is a major constraint to livestock and aggravated by drought occurrence. Very few respondents (1.8\%) practice rain water harvesting, however, watering livestock from wells and boreholes (65.3\%) was more practiced. While water harvesting refers to the collection of rainwater falling on the roofs of houses that are channelled through pipes into reservoirs for domestic use and watering of livestock, ground water is the utilisation of water from wells and or boreholes. To cope with extreme drought conditions, many of the respondents (88.2\%) also resorted to culling and selling some of the animals to maintain sizable herds. In certain case few animals are fattening before sale. The high dependence on natural vegetation makes it extremely difficult to access feed during drought period. This is demonstrated by the fact that few respondents (4.4\%) practiced forage cropping. This is a technic that involves pasture cultivation to increase forage availability for livestock. To adapt to the inadequacy of grazing land, the major adaptation strategies are: feed supplement (98.2\%), transhumance (97.0\% respondents), use of crop residues (93.4\%), fattening/destocking $(87.1 \%)$, use of fodder trees $(77.1 \%)$. Against the inadequate 
water supply, prayers and other rites (92.3\%), transhumance (90.8\%) and the use of ground water $(65.3 \%)$ are the principal strategies adapted by respondents. These adaptation strategies were quite similar to those highlighted by [24] [20]. However, the results were quite different from findings of [44] [45]. The author reported similar adaptation strategies consisting in the use of crop residue (98.4\%), the use of fodder trees (42.3\%), herd destocking (44.8\%). Furthermore, the author indicated more adaptation strategies beyond that mentioned by respondents such as: the adoption of agro-pastoralism (89.5\%), the use of concentrated feed $(80.6 \%)$ and vaccination $(91.9 \%)$. To cope with high diseases incidence, respondents identified prayers and others rites $(39.5 \%)$, transhumance $(37.3 \%)$ and feed supplement $(32.8 \%)$ as the major adaptation strategies. Other less practiced strategies were, abandonment of pastoral herding (6.3\%) destocking/fattening (3.3\%) use of crop residues (1.8\%) and use of fodder trees $(1.5 \%)$. Rainwater harvesting, use of ground water and forage cropping were not regarded as adaptation strategies for livestock diseases.

From respondents' point of view (Figure 4), the use of crop residues $(78.2 \%)$, fodder trees $(68.3 \%)$ and ground water $(60.1 \%)$, the destocking/fattening $(75.3 \%)$, the transhumance $(72.7 \%)$, prayers and other rites $(63.5 \%)$ and food

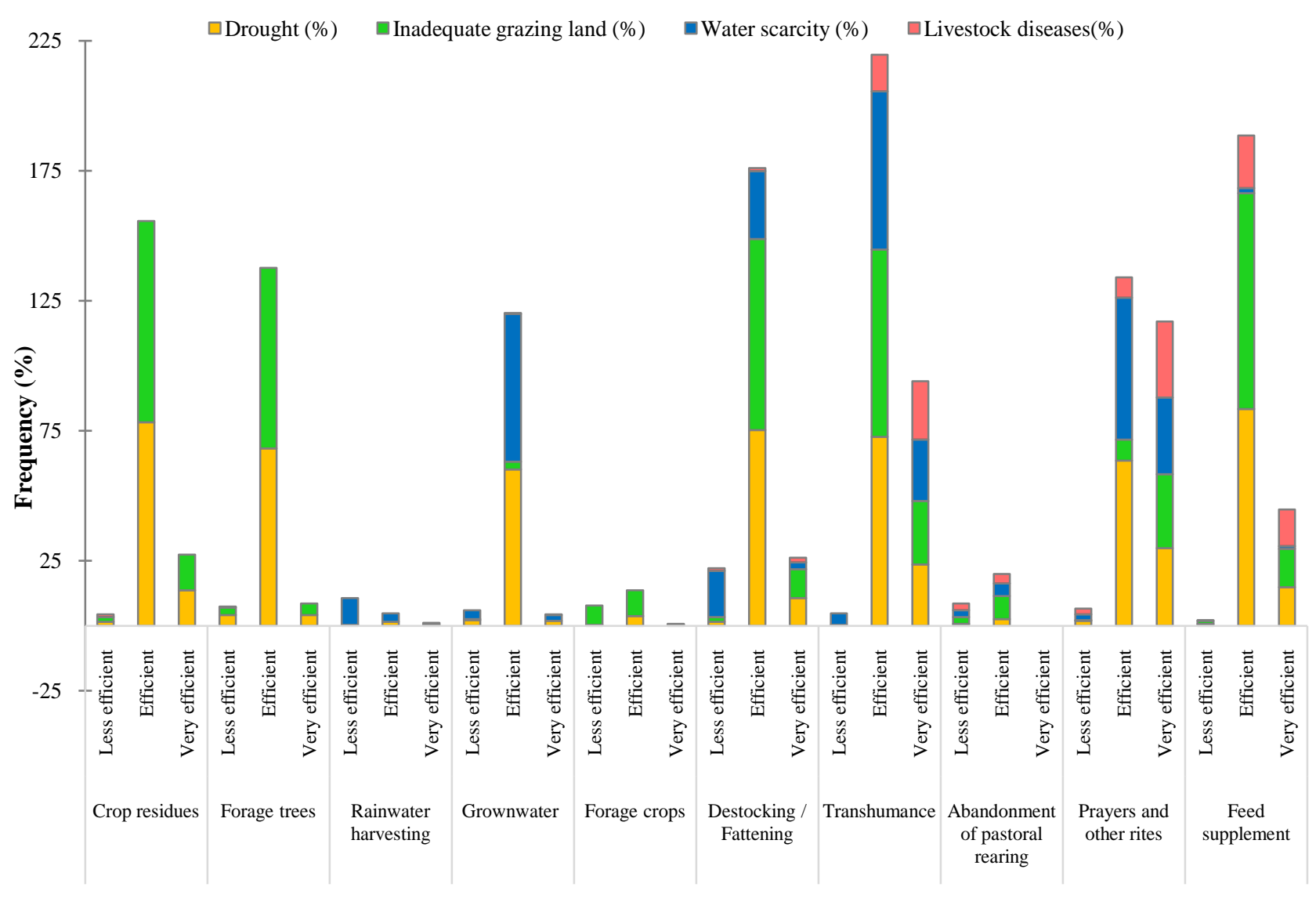

Adaptations strategies

Figure 4. Effectiveness of respondents' $(n=271)$ adaptive strategies to climate change impacts on their activities. 
supplement (83.4\%) are efficient adaptations actions to drought. Efficient adaptations measures to the lack of grazing are: crop residues (77.5\%), forage trees (69.4\%), destocking/fattening (73.4\%), transhumance (72.0\%), food supplement (83.0\%). To the lack of water, the efficient adaptation measure is the use of ground water (56.8\%), transhumance (60.8\%), prayers and other rites (54.6\%). Finally, against the occurrence of livestock diseases, none adopted measure appeared to be effective to the recrudescence of animal diseases. The effectiveness of ground water to adapt to climate changes is confirmed by [46]. Moreover, the effectiveness of livestock mobility, forage cropping, supplemental feeding and the use of groundwater were found to be an efficient adaptation practices to climate change and the extreme events [41].

Among all the practices the mobility (transhumance) is declared by farmers as the most effective strategy after feed supplement. Taking into account the socio-economic implications, mobility ahead of feed supplementation is more accessible to herders. However, for how long will herd mobility remain effective to climate change and variabilities? Facing the increasing challenges such as reduction of grazing lands and livestock routes, livestock mobility to adapt to climate change is likely to be compromised in the coming decades. From respondents' perspectives, current challenges faced by mobile herding is fuelling the recrudescence of violent conflicts between herders and crop farmers which in the long run is likely to stop transhumance. Indeed, on one hand violent conflicts were reported in Kompienga province within the villages of Nadiagou in 2013, Pama in 2014 and recently in 2015 within villages of Mamanga, Diapienga, Tibadi, Folpodi, Nimoutingou. The last conflict affected 106 Fulani camps, 343 houses burnt, 3.9 tons of by-product destroyed and about 80 tons of hay burnt 35 goats and sheep killed [47]. On the other hand, herders have experienced inside Togo, violent conflicts within villages of Kante, Namon and Kouka in 2017, within the village of Borgou in 2014, in the village of Bassar 2016 and 2017 and within the village of Djarakpana over the last five years. Finally, recent conflicts were also reported in Benin Republic (village of Datori) and in Ghana (village of Guschiegu) respectively in 2013 and 2016. These conflicts were characterized by loss of both human and livestock life orchestrated by crop farmers along transhumance routes. Pastoralists are facing more conflicts and taxes payment within Togo and nevertheless, they prefer moving into this country contrary to Ghana and Benin Republic. According to respondents, Togo offers more suitable environment for a best production and reproduction conditions of livestock. In this perspective, they asserted that rainfall and forage availability are earlier in Togo. Adequate availability of water and high forage quality in Togo appear to be the major factors that attract herders more than the other destinations. Indeed, transhumant pastoralists stipulated that forage in Benin Republic is highly contaminated with diseases. Each herd once back from Benin Republic, must be seriously treated to avoid mortalities due to diseases contracted during grazing. Less transhumance is noticed toward Ghana probably due to the distance. Furthermore, over last 
years, herders seem to move far and far southward within host countries (namely in Togo). Therefore, according to respondents, transhumant herds start visiting the village of Djarakpana only this last five (5) years (Figure 5). Given all the recent challenges, livestock mobility, a long-term adaptation strategy to harsh environment conditions, is no more playing this role unless sound and comprehensive solutions are found. Which solutions must settle a good and frank collaboration between herders and crops farmers within zones crossed by transhumant herds. Facing the future challenges such as deterioration of pastoral resources, respondents' strategies will be mainly the abandonment of pastoral rearing $(67.2 \%)$, the reduction of herds size $(65.3 \%)$ and activities diversifications (4.8\%). The abandonment of pastoral herding without adequate support to ensure availability of pasture might increase cattle mortality and consequently leading to food insecurity.

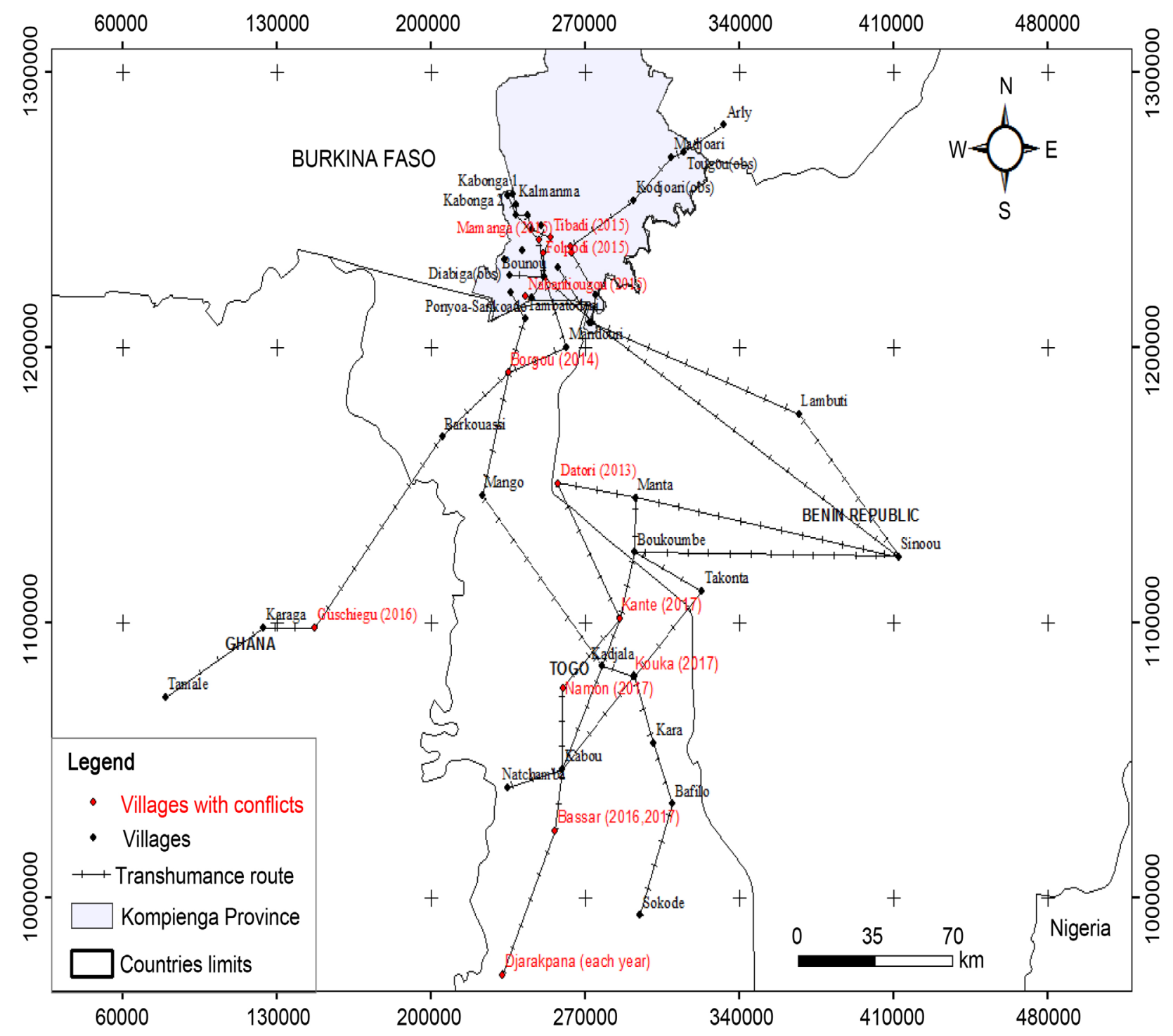

Figure 5. Transhumant herders mobilities from Kompienga province facing increasing challenges. 


\section{Conclusion}

From respondents' perspectives, changes in climate conditions as well as their impacts on mobile herding, are indisputable within Kompienga province. Globally, respondents noticed decrease in rainfall amount, a decrease in the number of rainy days and shift in rain onset (found later) and cessation (found earlier) while temperature, occurrences of strong winds, floods and animal's diseases were all regarded to be increasing. Deterioration in climate conditions affects livestock production and reproduction performance and herders' livelihoods. It results an increasing pressure/competition for natural resources with its corollary of conflicts within Kompienga province and host countries as well. Given all the recent challenges livestock mobility, a long-term adaptation strategy to harsh environment conditions, is no more playing this role unless sound and comprehensive solutions are found. In order to overcome the exacerbation of constraints related to mobile breeding, the Government of Burkina Faso urgently needs to undertake actions to reduce the number of transhumant herds and to increase the availability/accessibility of resources (feed, water) for livestock. This might be ensured by: 1) Providing all the grazing reserves with necessary facilities including adequate and continuous water supply and regenerate the pastures; 2) conducting research for the selection of improved breeds resistant to new climatic conditions; 3 ) encouraging and supporting gradual shift of herders from transhumance to the sedentary breeding; 4) supporting and organizing forage production by farmers. At short term an effective cross-border must be created to seek for sound solutions to secure the mobility of herds within ECOWAS ${ }^{4}$ territory.

\section{Acknowledgements}

We are grateful to the German Federal Ministry of Education and Research (BMBF) who funded this research work through West Africa Science Centre of Climate change and Adapted Land use (WASCAL). We are also grateful to all the respondents the workers of livestock and fishery extension services of Kompienga Province who facilitated the good achievement of my field work.

\section{References}

[1] World Bank (2009) Country Note on Disaster Risk Management and Adaptation to Climate Change in Burkina Faso. World Bank, Washington DC.

[2] Martin, R., Müller, B., Linstädter, A. and Frank, K. (2014) How Much Climate Change Can Pastoral Livelihoods Tolerate? Modelling Rangeland Use and Evaluating Risk. Global Environmental Change, 24, 183-192. https://doi.org/10.1016/j.gloenvcha.2013.09.009

[3] Swallow, B. (1994) The Role of Mobility within Risk Management Strategies of Pastoralists and Agropastoralists. Gatekeeper Series. http://pubs.iied.org/pdfs/6061IIED.pdf

${ }^{4}$ ECOWAS: Economic Community of West African States. 
[4] MRA (2010) National Livestock Sustainable Development Policy in Burkina Faso, PNDEL 2010. $201 \mathrm{p}$.

[5] Scoones, I. (1994) New Directions in Pastoral Development in Africa. In: Scoones, I., Ed., Living with Uncertainty: New Directions in Pastoral Development in Africa, London, 1-36. https://doi.org/10.1080/096145249100077821

[6] Turner, B.L., Meyer, W.B. and Skole, D.L. (1994) Global Land-Use Land-Cover Change: Towards an Integrated Study. Ambio, 23, 91-95.

[7] Amanor, K.S. (1995) Dynamics of Herd Structures and Herding Strategies in West Africa: A Study of Market Integration and Ecological Adaptation. Journal of the International African Institute, 65.

http://www.jstor.org/page/info/about/policies/terms.jsp https://doi.org/10.2307/1161051

[8] Niamir-Fuller, M. (2000) Managing Mobility in African Rangelands. In: McCarthy, N., Swallow, B., Kirk, M. and Hazell, P., Eds., Property Rights, Risk, and Livestock Development in Africa, International Food Policy Research Institute, Washington DC, 435. https://cgspace.cgiar.org/handle/10568/50993

[9] Thébaud, B. and Batterbury, S. (2001) Sahel Pastoralists: Opportunism, Struggle, Conflict and Negotiation. A Case Study from Eastern Niger. Global Environmental Change, 11, 69-78. https://doi.org/10.1016/S0959-3780(00)00046-7

[10] Mccarthy, N. and Di Gregorio, M. (2007) Climate Variability and Flexibility in Resource Access: The Case of Pastoral Mobility in Northern Kenya. Environment and Development Economics, 12, 403. https://doi.org/10.1017/S1355770X07003609

[11] Adriansen, H.K. (2008) Understanding Pastoral Mobility: The Case of Senegalese Fulani. Geographical Journal, 174, 207-222. http://doi.org/10.1111/j.1475-4959.2008.00278.x

[12] Gonin, A. and Gautier, D. (2015) Shift in Herders' Territorialities from Regional to Local Scale: The Political Ecology of Pastoral Herding in Western Burkina Faso. Pastoralism, 5, 7. https://doi.org/10.1186/s13570-015-0023-z

[13] Gonin, A. (2014) Power Games for Access to Resources and Future of Livestock in Sudanian Africa. Pastoral Land in Western Burkina Faso. Ph.D. Thesis, University Paris 1 Panthéon-Sorbonne, Paris.

[14] Larsson, H. (1995) Historical Review of Vegetation and Land Use in Kassala Province, Eastern Sudan. Geografiska Annaler, 77, 135-146. http://www.jstor.org/stable/521226

[15] Reenberg, A., Oksen, P. and Svendsen, J. (2003) Land Use Changes vis-à-vis Agricultural Development in Southeastern Burkina Faso: The Field Expansion Dilemma. Geografisk Tidsskrift, 103, 57-69. https://doi.org/10.1080/00167223.2003.10649492

[16] Lambin, E.F., Geist, H.J. and Lepers, E. (2003) Dynamics of Land-Use and Land-Cover Change in Tropical Regions. Annual Review of Environment and Resources, 28, 205-241. https://doi.org/10.1146/annurev.energy.28.050302.105459

[17] Sulieman, H.M. (2010) Expansion of Mechanised Rain-Fed Agriculture and Land-Use/Land-Cover Change in the Southern Gadarif, Sudan. African Journal of Agricultural Research, 5, 1609-1615.

[18] Sulieman, H.M. and Elagib, N.A. (2012) Implications of Climate, Land-Use and Land-Cover Changes for Pastoralism in Eastern Sudan. Journal of Arid Environments, 85, 132-141. http://doi.org/10.1016/j.jaridenv.2012.05.001

[19] Byenkya, G.S., Mugerwa, S., Barasa, S. and Zziwa, E. (2014) Land Use and Cover Change in Pastoral Systems of Uganda: Implications on Livestock Management 
under Drought Induced Pasture. African Crop Science Journal, 22, 1013-1025.

[20] Zampaligré, N., Dossa, L.H. and Schlecht, E. (2013) Climate Change and Variability: Perception and Adaptation Strategies of Pastoralists and Agro-Pastoralists across Different Zones of Burkina Faso. Regional Environmental Change, 14, 769-783. http://doi.org/10.1007/s10113-013-0532-5

[21] Kimiti, K.S., Wasonga, O.V., Western, D. and Mbau, J.S. (2016) Community Perceptions on Spatio-Temporal Land Use Changes in the Amboseli Ecosystem, Southern Kenya. Pastoralism, 6, 24. http://doi.org/10.1186/s13570-016-0070-0

[22] Breusers, M. (2001) Searching for Livelihood Security: Land and Mobility in Burkina Faso. Journal of Development Studies, 37, 49-80.

[23] Sawadogo, I. (2011) Fodder Resources and Representations of Pastoralists, Evolution of Pastoral Practices in a Protected Area Context: Case of the Kotchari Terroir on the Outskirts of the W Biosphere Reserve in Burkina Faso. Ph.D. Thesis, National Museum of Natural History, Washington, DC, $336 \mathrm{p}$.

[24] Kiema, A., Some, L., Nacro, B.H., Compaore, H., Kagone, H. and Kpoda, C.S.Y. (2013) Adaptation Strategy of Pastoralists in the Eastern Zone of Burkina Faso to the Effects of Climate Change. African Agronomy Special Issue on Climate Change, 79, 67-79.

[25] Gomgnimbou, A.P.K., Savadogo, P.W., Nianogo, A.J. and Millogo-Rasolodimby, J. (2010) Farming Practices and Farmers' Perceptions of the Environmental Impacts of Cotton Farming in the Province of Kompienga (Burkina Faso). Science \& Nature, 7, 165-175. http://doi.org/10.4314/scinat.v7i2.59960

[26] Soungalo, S. (2016) Land Use Patterns and Indicators of Biodiversity Degradation in Pama Reserves and Agrosystems (South-East Burkina Faso). PhD Thesis, Ouaga University I Pr Joseph KI-ZERBO, Burkina Faso, 165 p.

[27] Dipama, J.-M., Vissin, E.W., Hedible, S. and Boko, M. (2011) Analysis of Strategies of Agricultural Practices Facing Climate Change within Kompienga (Burkina Faso) and Mekrou (Benin). Annals of the University of Ouagadougou, 13, 73.

[28] Mbayngone, E., Thiombiano, A., Hahn-Hadjaki, K. and Guinko, S. (2008) Structure of the Woody Species of Plant Formations of the Pama Reserve (South-East Burkina Faso, West Africa). Flora et Vegetatio Sudano-Sambesica, 11, 25-34. https://www.researchgate.net/publication/290306433

[29] Fontès, J. and Guinko, S. (1995) Map of the Vegetation and Land Cover of Burkina Faso. National Center for Scientific Research of the University of Toulouse III, Institute of Rural Development, Faculty of Science and Technology of the University of Ouagadougou, Ministry of French Cooperation, Campus Project 88313101, 65 p.

[30] Hahn-Hadjali, K. (1998) The Savanna Plant Communities of South-Eastern Burkina Faso (West Africa). Studies on Flora and Vegetation of Burkina Faso and Neighbouring Countries, 3, 3-79.

[31] INSD $^{5}$ (2009) Statistical Yearbook. INSD, Ouagadougou, Burkina Faso.

[32] INSD (2014) Statistical Yearbook 2013. INSD, Ouagadougou, Burkina Faso.

[33] Kima, S.A., Okhimanhe, A.A. and Kiema, A. (2016) Assessing the Impacts of Land Use and Land Cover Change on Pastoral Livestock Farming in South-Eastern Burkina Faso. Environment and Natural Resources Research, 6, 110. http://doi.org/10.5539/enrr.v6n1p110

[34] Akponikpè, P.B.I., Johnston, P. and Agbossou, E.K. (2010) Farmers' Perception of ${ }^{5}$ INSD: Institut national de la statistique et de la démographie (National Institute of Statistics and Demography). 
Climate Change and Adaptation Strategies in Sub-Saharan West-Africa. 2nd International Conference: Climate, Sustainability and Development in Semi-Arid Regions, Fortaleza-Ceará, 16-20 August 2010. https://www.researchgate.net/profile/Peter_Johnston4/publication/265798407

[35] Ouédraogo, M., Dembélé, Y. and Somé, L. (2010) Perceptions and Strategies for Adapting to Changes in Rainfall: The Case of Farmers in Burkina Faso. Drought, 20, 32-38. http://doi.org/10.1684/sec.2010.0256

[36] Allé, U.C.S.Y., Vissoh, P., Guibert, H., Agbossou, E. and Afouda, A.A. (2013) Relationship between Farmers' Perceptions of Climatic Variability and Climatic Observations in South Benin. VertigO-The Electronic Journal in Environmental Sciences, 13, 14. http://doi.org/10.4000/vertigo.14361

[37] Sanfo, A. (2014) Climate Change and Human Security: The Case of Violent Conflicts between Crop Farmers and Agropastoralists in the Eastern and Plateau Central Regions of Burkina Faso, West Africa. Master Thesis, University of Lomé, Togo, $65 \mathrm{p}$.

[38] Gentle, P. and Thwaites, R. (2016) Transhumant Pastoralism in the Context of Socioeconomic and Climate Change in the Mountains of Nepal. Mountain Research and Development, 36, 173-182. http://doi.org/10.1659/MRD-JOURNAL-D-15-00011.1

[39] Sirohi, S. and Michaelowa, A. (2007) Sufferer and Cause: Indian Livestock and Climate Change. Climatic Change, 85, 285-298. http://doi.org/10.1007/s10584-007-9241-8

[40] Thornton, P., Herrero, M., Freeman, A. and Mwai, O. (2007) Vulnerability, Climate change and Livestock-Research Opportunities and Challenges for Poverty Alleviation. SAT Journal, 4, 171.

[41] Asian Development Bank (2013) Making Grasslands Sustainable in Mongolia: Adapting to Climate and Environmental Change. Asian Development Bank, Mandaluyong City, Philippines.

[42] MAEH (Ministry of Agriculture of Livestock and Hydraulics of Togo) (2016) Operational Plan of Management of Transhumance (POGT-2017). MAEH, Togo, $62 \mathrm{p}$.

[43] MAEP (Ministry of Agriculture, Livestock and Fisheries of Benin) (2017) Interministerial Order No. 2017-002/MAEP/MISP/DC/SGM/DE/SA/002SGG17 Amending the Interministerial Decree No. 270/MISP/MAEP/DC/SGM/SA/125SGG16 of 25 November 2016 on the Details of the 2016-2017 Transhumance Campaign in the Republic of Benin. MAEP, Benin, $7 \mathrm{p}$.

[44] Kima, S.A. (2014) Assessment of the Impact of Climate and Land Use Changes on pastoral Livestock Farming in Boulgou Province, South-Eastern Burkina Faso. Master Thesis, Federal University of Minna, Minna, Nigeria, 118 p.

[45] Kima, S.A., Okhimamhe, A.A., Kiema, A., Zampaligre, N. and Sule, I. (2015) Adapting to the Impacts of Climate Change in the Sub-Humid Zone of Burkina Faso, West Africa: Perceptions of Agro-Pastoralists. Pastoralism, 5, 16. http://doi.org/10.1186/s13570-015-0034-9

[46] Masike, S. (2007) The Impacts of Climate Change on Cattle Water Demand and Supply in Khurutshe, Botswana. PhD Thesis, University of Waikato, Hamilton, 330 p.

[47] ZATE $^{6}$ (2015) Inventory and Damage Assessment Report Related to Animal Resources That Took Place on 17/01/2015 in Five Villages in Kompienga Province. ZATE, Kompienga, Burkina Faso, 8 p.

${ }^{6}$ ZATE : Zone d'Appui Technique en Elevage (Technical Support Zone in Livestock). 